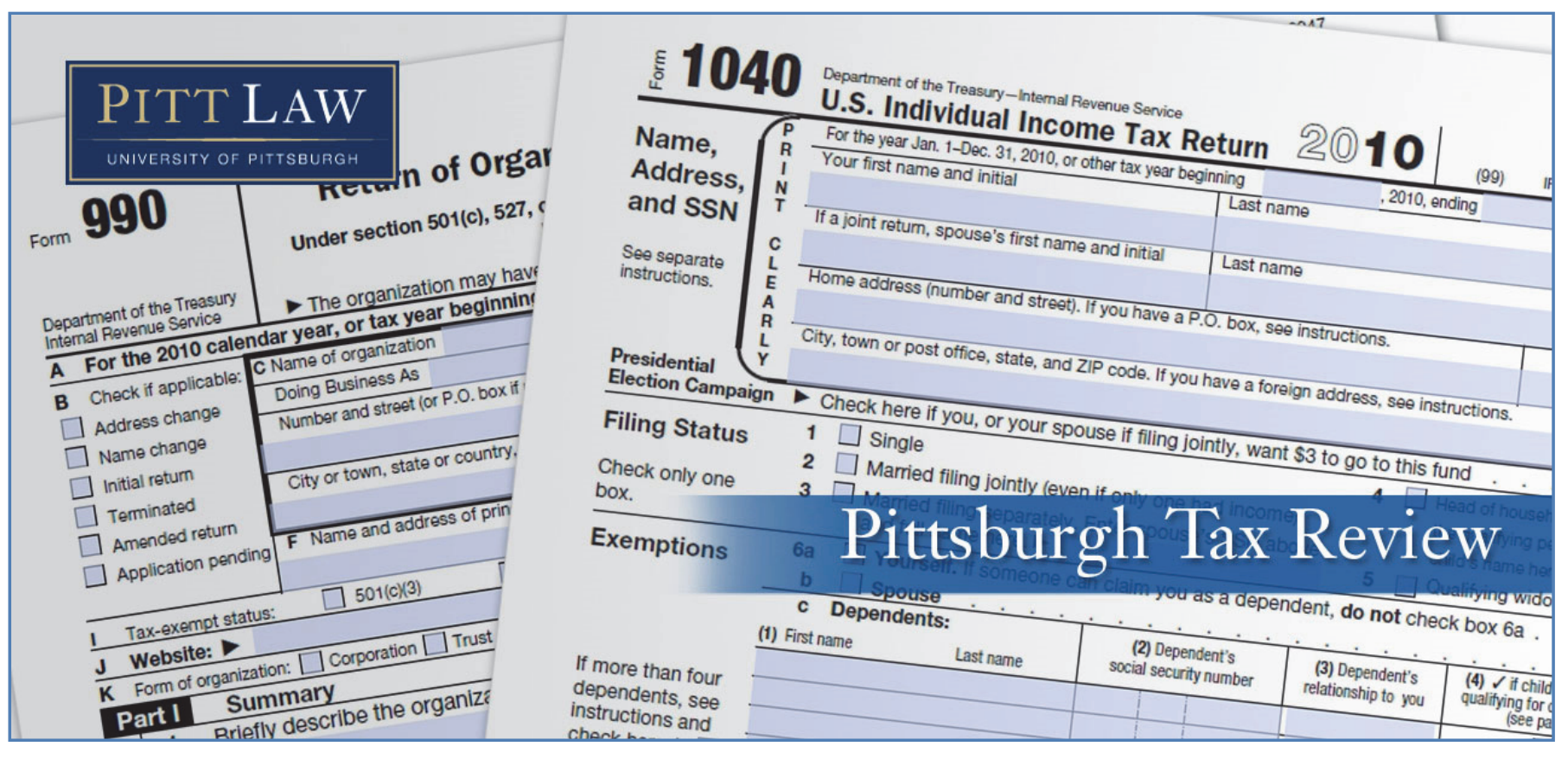

Volume 16 (2019) | ISSN 1932-1821 (print) 1932-1996 (online)

DOI 10.5195/taxreview.2019.95 | http://taxreview.law.pitt.edu

\author{
UNITED STATES $v$. DAVIS AND PROF. CAIN'S REWRITTEN \\ OPINION: AN INTERSECTIONAL ARGUMENT FOR CAPPING \\ SECTION 1041
}

\title{
Diane Klein
}

\section{(c)) BY-NC-ND}

This work is licensed under a Creative Commons Attribution-Noncommercial-No Derivative Works 3.0 United States License.

\section{ULIS D-Sork}

This journal is published by the University Library System of the University of Pittsburgh as part of its D-Scribe Digital Publishing Program, and is cosponsored by the University of Pittsburgh Press. 


\title{
UNITED STATES $v$. DAVIS AND PROF. CAIN'S REWRITTEN OPINION: AN INTERSECTIONAL ARGUMENT FOR CAPPING SECTION 1041
}

\author{
Diane Klein ${ }^{*}$
}

Tax cases are about rich people. Given the demographic distribution of income and wealth in the United States, ${ }^{1}$ that means tax cases are mostly about rich white people.

How rich? The transfer at issue in United States v. Davis, part of the marital dissolution settlement paid to Alice Davis by her ex-husband Thomas, consisted of shares of appreciated DuPont stock worth $\$ 82,250$ in $1955 .^{2}$ In that year, the median net worth of American households was $\$ 4,100{ }^{3}$ In current dollars, that transfer would be worth almost $\$ 760,000^{4}$ and this was only half of the stock she was to receive. And that's not all-

\footnotetext{
* Professor of Law, University of La Verne College of Law. AB, Harvard; JD, University of California, Los Angeles School of Law; LLM, University of San Francisco School of Law. My thanks to Professors Bridget Crawford and Anthony Infanti, for editing the volume of rewritten tax opinions and for soliciting additional commentary. As a newcomer to tax scholarship, my special thanks to Professors Victoria Haneman and Julie Young for their input; any errors are of course my own. Please note that the words black and white, when referring to race or ethnicity, have been lowercased in this essay to accord with the general preference of the Chicago Manual of Style, which is followed by the Pittsburgh Tax Review on questions not addressed by the Bluebook.

${ }^{1}$ Brian Thompson, The Racial Wealth Gap: Addressing America's Most Pressing Epidemic, FORBES (Feb. 18, 2018, 12:15 PM), https://www.forbes.com/sites/brianthompson1/2018/02/18/theracial-wealth-gap-addressing-americas-most-pressing-epidemic/\#437c781f7a48; Serena Lei, Nine Charts About Wealth Inequality in America (Updated), URBAN INST., http://apps.urban.org/features/wealthinequality-charts/ (last updated Oct. 5, 2017).

${ }^{2}$ Linda M. Beale, Commentary on United States v. Davis, in Feminist Judgments: Rewritten TAX OpINIONS 121 (Bridget J. Crawford \& Anthony C. Infanti eds., 2017).

${ }^{3}$ Bureau of the Census, U.S. Dept. of Commerce, Statistical Abstract of the United StATES: 1955, at 303 tbl.362 (1955) (table titled "Persons With Wage or Salary Income-Percent Distribution by Wage or Salary Income, by Sex: 1939, 1952, and 1953"), available at https:// www2.census.gov/library/publications/1955/compendia/statab/76ed/1955-03.pdf?.

${ }^{4}$ Inflation Calculator: The Changing Value of a Dollar, DOLLARTIMES, https://www.dollartimes .com/inflation/inflation.php?amount=99000\&year=1955 (last visited Apr. 14, 2019) (inflation calculation of $\$ 82,250$ in 1955 to present value in 2019).
}

Pitt Tax Review | ISSN 1932-1821 (print) 1932-1996 (online)

DOI 10.5195/taxreview.2019.95 | http://taxreview.law.pitt.edu 


\section{6 | Pittsburgh Tax Review | Vol. 162019}

Alice's settlement also included a cash payment and ongoing maintenance and support for Alice; a trust fund for their son, Thomas, Jr.; and certain life insurance policies ${ }^{5}$ (which turned out to be a wise choice, as Thomas died in $\left.1964^{6}\right)$.

It is easy to lose sight of the rarified circumstances at issue in a case like this - or rather, never to notice them at all, because tax opinions never address them. The gender, race, and class of the litigants are not "relevant," so the thinking goes, and so they are almost never mentioned. Davis is no exception.

The tax issue in Davis can be stated simply: when shall transfers of appreciated assets incident to divorce be taxed? In 1962, when Davis was decided, ${ }^{7}$ this question did not arise in community property states because the division of the community estate was not treated as a "transfer" at all (but as a division of jointly owned property). ${ }^{8}$ In holding that the transfer was taxable when made if the spouses divorced in a common law state, "the Supreme Court [in Davis] achieved uniformity in treatment of transfers of appreciated property ... but created inconsistency in treatment of marital property settlements based upon the residence of the taxpayers in a common law or a community property state." "Ultimately, this inconsistency became politically untenable, and Congress enacted $\S 1041$, which provides that all such transfers are tax free. ${ }^{10}$

Patricia Cain's partial dissenting opinion in Feminist Judgments is to the same effect: "the Court should treat common law property wives the same" as community property wives. ${ }^{11}$ Her argument for equality of treatment is

${ }^{5}$ See Karen B. Brown, The Story of Davis: Transfers of Property Pursuant to Divorce, in TAX StORIES 171 (Paul L. Caron ed., 2d ed. 2009).

${ }^{6}$ Thomas Crawley Davis Is Dead, N.Y. TIMES (Feb. 1, 1964), https://www.nytimes.com/1964/02/ 01/thomas-crawley-davis-is-dead.html [hereinafter Davis Obituary].

${ }^{7}$ Beale, supra note 2, at 121.

${ }^{8}$ See, e.g., Comm'r v. Mills, 183 F.2d 32, 34 (9th Cir. 1950).

${ }^{9}$ Brown, supra note 5, at 184 .

${ }^{10}$ I.R.C. $\$ 1041$ (a) ("No gain or loss shall be recognized on a transfer of property from an individual to $\ldots$ a former spouse" so long as "the transfer is incident to divorce").

${ }^{11}$ Patricia A. Cain, United States v. Davis, in Feminist Judgments, supra note 2, at 134.

Pitt Tax Review | ISSN 1932-1821 (print) 1932-1996 (online) DOI 10.5195/taxreview.2019.95 | http://taxreview.law.pitt.edu 
premised importantly upon her showing that (as of 1962), wives in community property states had significantly fewer, and wives in common law property states perhaps more, legal rights in maritally acquired property than is usually acknowledged, rendering the two functionally more alike than different and undermining arguments for differential treatment. ${ }^{12}$ And this is surely correct, as far as it goes.

But thinking about these rules only from the point of view of the taxpayers themselves, and what is "fair" inter se or as compared to others similarly situated, may distract us from seeing broader issues also properly considered in tax policy. When we take into account not just sex, gender, and marital status but also race and class, the focus on one sort of inequality (between divorcing couples in different states) obscures another inequality that is larger and more far-reaching (race-based wealth inequality). To address this, I suggest an amendment to $\S 1041$ - a limit on tax-free transfers of appreciated assets incident to divorce. The cap is intended to balance desirable flexibility and asset preservation at divorce with legitimate fiscal and equity concerns in what at least aspires to be a progressive tax system. ${ }^{13}$

Thus, there is still much to be learned from Davis, although the opinion addressing it reveals little about the larger social and economic situation of this 1955 divorce between a highly placed Delaware executive and his wife. The case comes to us from a nearly vanished world, something like the one so vividly depicted in the AMC show Mad Men. ${ }^{14}$ Linda Beale's commentary and Patricia Cain's opinion bring the realities of gender and marriage law to bear on the issue, ${ }^{15}$ and I hope to add some further perspectives using race and class.

\footnotetext{
${ }^{12} I d$. at 135 .

${ }^{13}$ A much more radical (and less politically viable) option would be recognition of $100 \%$ of all gain upon transfer, perhaps subject to an exception, linked to $\S 121$, for the family home. The argument for such a proposal goes beyond what can be done here, though it can, I believe, be defended in principle.

${ }^{14}$ Mad Men, WIKIPEDIA, https://en.wikipedia.org/wiki/Mad_Men (last visited Apr. 14, 2019). Thomas Davis, born in 1901, would be closest in age to the character "Bert Cooper," though in lifestyle it appears he more closely resembled "Roger Sterling." Id.

${ }^{15}$ Cain, supra note 11, at 129-39; Beal, supra note 2, at 121-29.
}

Pitt Tax Review | ISSN 1932-1821 (print) 1932-1996 (online) DOI 10.5195/taxreview.2019.95 | http://taxreview.law.pitt.edu 
The taxpayer, ${ }^{16}$ Thomas Crawley Davis, married Alice in 1941 when he was already a forty-year-old, college-educated C.P.A. ${ }^{17}$ At a time when fewer than one American in twenty had a bachelor's degree (just over one in a hundred among black Americans), ${ }^{18}$ Thomas had not only done graduate work at Columbia but had also taught there. ${ }^{19}$

In 1955, the year the Davises split, Fortune magazine inaugurated the "Fortune 500," and published an article about "How Top Executives Live.,"20 The article described the lifestyles of the 30,000 American executives earning $\$ 50,000$ or more in that year (the median income for white men in the United States was $\$ 3,760$ at that time). ${ }^{21}$ The Davises lived in Delaware, where Thomas was a vice president and director of DuPont, as well as a vice president, director, and member of the executive committee of the American Management Association - exactly the sort of man profiled by Fortune (and eulogized by The New York Times when he $\operatorname{died}^{22}$ ). We can only speculate as to whether Thomas shared any of his boss Crawford Greenewalt's hobbies: "a home machine shop, goggle fishing off his Bermuda home, tennis, the clarinet, classical recordings, the photography of birds, and the cultivation of orchids." ${ }^{23}$ Nor can we know for sure whether he shared the views of his colleague at the Management Association, Sylvania Electric Products Co. executive Don Mitchell, who said about his wife: "Her job is to bring up the children ... and keep my health reasonably good." 24

\footnotetext{
${ }^{16}$ As Beale notes, the return in question is actually a joint return, filed by Thomas with his second wife, Grace. The Court makes short work of this, and the commentators do not say a great deal more. Beale, supra note 2, at 122 .

${ }^{17}$ Davis Obituary, supra note 6.

${ }^{18}$ Educational Attainment by Race and Hispanic Origin, 1940-2014, INFOPLEASE, https:// www.infoplease.com/us/school-enrollment-and-educational-attainment/educational-attainment-raceand-hispanic-origin (last visited Apr. 14, 2019).

${ }^{19}$ See Davis Obituary, supra note 6.

${ }^{20}$ Duncan Norton-Taylor, How Top Executives Live (Fortune, 1955), ForTunE (May 6, 2012), http://fortune.com/2012/05/06/how-top-executives-live-fortune-1955/.

${ }^{21}$ Bureau of The Census, supra note 3, at 303.

${ }^{22}$ See Davis Obituary, supra note 6.

${ }^{23}$ See Norton-Taylor, supra note 20.

${ }^{24} \mathrm{Id}$.
}

Pitt Tax Review | ISSN 1932-1821 (print) 1932-1996 (online) DOI 10.5195/taxreview.2019.95 | http://taxreview.law.pitt.edu 
While it lasted, the Davis nuclear family fit right in. In 1950, ninety-one percent of all households in Delaware consisted of married couples (with or without children). ${ }^{25}$ As a 1973 ABA Journal article accurately stated about Delaware at that time, "Divorces were hard to obtain, and the divorce rate was low." ${ }^{26}$ Delaware did not adopt no-fault divorce until 1957; until then, a fault ground (like adultery, bigamy, felony, habitual drunkenness, or "congenital inability to support a family") was required. ${ }^{27}$ In 1950 (the closest year for which statistics are available), approximately two-thirds of all divorces were granted to wives, meaning, the wife was the petitioner. ${ }^{28}$ Still, rather than engage with difficult Delaware divorce law, Alice sought and obtained a divorce in Reno, Nevada, in $1955^{29}$ based on "extreme mental cruelty," as was common at the time (Betty Draper obtained a Reno divorce on the season three finale of $\mathrm{Mad} \mathrm{Men}^{30}$ ). Thomas remarried the same year, suggesting that perhaps Fortune missed the mark when it stated, "Extramarital relations in the top American business world are not important enough to discuss." $" 31$

After the divorce itself came the property settlement. As described above, it included a significant amount of appreciated DuPont stock (which Thomas received as a corporate executive), raising the tax issue. The result reached in Davis - that the transferor spouse realizes a gain and the transferee spouse takes a fair market value basis - is described as "a generous result for the wife (or transferee spouse generally)," occurring despite

${ }^{25}$ Edward C. Ratledge \& David P. Racca, Ctr. For Applied Demography \& Survey RESEARCh, DeMOgRaPhiC AND COMMUTING TRENDS IN DELAWARE 15 (1996), http://128.175.63.72/ projects/DOCUMENTS/florida7.pdf.

${ }^{26}$ John T. Gallagher, No Fault Divorce in Delaware, 59 A.B.A. J. 873, 873 (1973).

${ }^{27} I d$.

${ }^{28}$ See U.S. Dep'T of Health Educ. \& Welfare, Pub. Health Serv., 100 Years of Marriage AND DivORCE StATISTICS UNITED STATES, 1867-1967, at 18 (1973), https://www.cdc.gov/nchs/data/ series/sr_21/sr21_024.pdf. This does not mean the wife was actually the instigating party; in fault divorce states, divorce-seeking husbands were often willing to be publicly accused of adultery or another basis for divorce; who would sue whom, and on what ground, was part of the divorce negotiation. Id.

${ }^{29}$ See United States v. Davis, 370 U.S. 65, 67 (1962).

${ }^{30}$ Mad Men: Shut the Door. Have a Seat. (AMC television broadcast Nov. 8, 2009).

${ }^{31}$ Norton-Taylor, supra note 20.

Pitt Tax Review | ISSN 1932-1821 (print) 1932-1996 (online) DOI 10.5195/taxreview.2019.95 | http://taxreview.law.pitt.edu 


\section{0 | Pittsburgh Tax Review | Vol. 162019}

the understanding that the wife would in most cases have no basis in her marital rights .... Treatment of her relinquishment of marital rights as a taxable event would guarantee that she would include in gross income the full fair market value of the property received. This would result in a hardship to the wife, who would be required to sell the property in order to pay the taxes . . . ${ }^{32}$

As Karen Brown noted, criticizing the holding:

Mrs. Davis was accorded better treatment than similarly situated persons . . . . The decision not to tax the transferor of marital rights presumably was based either upon the Court's determination not to impose a tax on the wife at the same time that she was undergoing the hardship of divorce or upon its determination that marital rights did not amount to property that could be transferred..$^{33}$

This notion of "hardship" is a theme in commentary about Davis. Another commentator describes Davis as "impos[ing] a heavy tax burden at the worst possible time - when a couple's finances were in disarray and every available dollar was needed to finance the transition from one household into two." ${ }^{34}$ In her rewritten tax opinion, Cain refers to "[w]ives who are like Mrs. Davis, who have no other income, and who are selling the property in order to support themselves"-wives who, under Davis, "may pay little or no taxes on the sales." ${ }^{35}$

But is this an accurate depiction of the circumstances of divorcing couples whose marital estate includes appreciated assets? Determining the tax consequences of the transfer of such assets as part of a divorce settlement is the sort of problem faced only by those whose marital estates contain appreciated assets worth enough to litigate with the IRS about. The Davis marital estate contained that - and much more. Recall that Alice's settlement also included cash and ongoing maintenance for her to live upon. Although she was not (so far as we know) gainfully employed, describing her as having "no other income" is not correct. By contrast, if "every available dollar" really is needed to maintain one household and set up a second, one spouse or the other will have to liquidate the transferred property anyway. Whether the taxes are imposed on the transferor or the transferee, the former marital

\footnotetext{
${ }^{32}$ Brown, supra note 5, at 183.

${ }^{33} \mathrm{Id}$. at $189-90$.

${ }^{34} I d$. at 184.

${ }^{35}$ Cain, supra note 11 , at 136.
}

Pitt Tax Review | ISSN 1932-1821 (print) 1932-1996 (online) DOI 10.5195/taxreview.2019.95 | http://taxreview.law.pitt.edu 
estate will bear the burden. Davis, thus, does not provide effective tax relief to those of more modest circumstances with nothing to transfer but appreciated assets.

In her commentary, Beale describes Cain's dissent as assessing the impact of Davis "on women generally — not just Alice Davis, but divorcing wives in all the range of circumstances in which they find themselves at the moment of divorce." 36 But does Cain's analysis really reach beyond the narrowest white upper-class circumstances? Those with stock to transfer are already disproportionately white. Even among those at equal income levels today, white people own stock at significantly higher rates than black people, a fact which has contributed significantly to race-based wealth disparities. ${ }^{37}$ Cain notes, without emphasis, that the husbands affected by the rule in Davis "are typically high-income individuals." ${ }^{38}$ The unstated corollary of this is that most divorcing men and women, particularly persons of color, would not be impacted directly by Davis at all - they simply are not rich enough. At most, Cain assesses the impact on families "similar to the Davis family," in which, echoing Don Mitchell in Fortune, "[h]usbands would work in the marketplace. Wives would stay home and have babies, care for them, and provide basic support for husbands." 39

Like the original opinion in Davis, Cain's rewritten dissent never mentions race. But race matters. In 1940, the labor force participation of white married women was just $12.5 \%$, rising to $20.7 \%$ in $1950 .{ }^{40}$ But for nonwhite married women, the figures are significantly higher: $27.3 \%$ and $31.8 \%$, respectively. ${ }^{41}$ This gap was not an anomaly; as one scholar noted,

\footnotetext{
${ }^{36}$ Beale, supra note 2, at 128.

37 Study Finds Race Plays Role in Investing, ABC NEWs (June 6, 2018), https://abcnews .go.com/Business/story?id=88110\&page=1 [https://web.archive.org/web/20180924114254/https:// abcnews.go.com/Business/story?id=88110\&page=1]; Jeffrey M. Jones, U.S. Stock Ownership down Among All but Older, Higher-Income, GALLUP (May 24, 2017), https://news.gallup.com/poll/211052/ stock-ownership-down-among-older-higher-income.aspx.

${ }^{38}$ Cain, supra note 11 , at 136.

${ }^{39} \mathrm{Id}$. at 131.

${ }^{40}$ Claudia Goldin, Female Labor Force Participation: The Origin of Black and White Differences, 1870 and 1880, 37 J. ECON. HIST. 87, 88 (1977).

${ }^{41} I d$.
}

Pitt Tax Review | ISSN 1932-1821 (print) 1932-1996 (online) DOI 10.5195/taxreview.2019.95 | http://taxreview.law.pitt.edu 


\section{2 | Pittsburgh Tax Review | Vol. 162019}

"Married black and white women have had different labor force participation rates throughout American history .... The almost total lack of wealth among black families implied that the unemployment of the primary worker, usually the husband, was a harsh reality which doubtless forced other family members into the labor force." ${ }^{42}$ These patterns reflect the long-term effects of slavery and racism, "those that influence earning power, asset accumulation, and family structure. $" 43$

Cain is not wholly insensitive to issues of class and class expectations on a wife like Alice Davis, who must "entertain business associates and arrange social functions that would help smooth a husband's rise to the top." 44 But it is distressing that Cain's analysis seems less cognizant of the structure of household labor than Fortune magazine in 1955, which, while it lamented that the households of American executives were reduced to just one or two "servants," at least acknowledged their existence.

Cain argues that the majority opinion in Davis "denies the reality of the situation in which these two taxpayers experienced this transaction." 45 But Cain's argument is more prescriptive than descriptive about the legal marital relationship as it existed in the 1960s: she analogizes divorce to a "dissolution of partnership" because she believes "wives should be, in the eyes of the law,

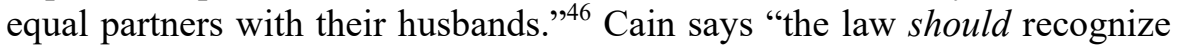
both spouses as equal bargainers in the beginning," because "[e]ach had the ability to say yes or no to the formation of the partnership." 47 Thus, "we should view marriage as a partnership." 48 But this technical, formalistic/legalistic approach also denies reality - the real inequality in bargaining power that existed then (and exists now) between the sexes due to women's lesser earning power and economic opportunity, and to social stigma attached to unmarried status.

\footnotetext{
${ }^{42} I d$. at 101.

${ }^{43} I d$. at 102.

${ }^{44}$ Cain, supra note 11 , at 132.

${ }^{45} I d$. at 130.

${ }^{46} I d$. (emphasis added).

${ }^{47} I d$. at 131 (emphasis added).

${ }^{48} I d$. at 130 (emphasis added).
}

Pitt Tax Review | ISSN 1932-1821 (print) 1932-1996 (online) DOI 10.5195/taxreview.2019.95 | http://taxreview.law.pitt.edu 
Whether we treat divorcing spouses with appreciated assets as if they were former business partners, arm's-length bargainers, or persons animated mostly by charity and affection (and Cain considers all of these), we are still talking about a small group of highly privileged, mostly white, people. If we broaden our view enough to take in all the Americans benefited by a healthy public fisc and unlikely to be directly affected by these rules, all of those benefited by increased tax revenues in a generally progressive tax system, we see nearly everyone, and most especially, nearly every nonwhite person.

Compared to 1962, the racialized concentration of wealth, including ownership of equities like the appreciated DuPont stock in Davis, has gotten worse, not better. ${ }^{49}$ Rather than asking whether facially race-neutral tax rules unfairly or irrationally discriminate against rich white couples in Delaware compared to those in California, we should ask instead why the transfer of appreciated assets, ordinarily a recognition event, should be treated favorably and exempted from taxation, simply because the transferor and transferee happen to be divorcing spouses in any state. The burden should be on those defending a tax provision whose benefits are enjoyed almost exclusively by the richest (and mostly white) formerly married people in America - and paid for by everyone else. Why should this transfer, among all transfers of appreciated assets, be free from tax? Why not at least impose a cap?

Such an approach is not novel. For example, $\S 121$ permits taxpayers to exclude capital gain of up to $\$ 250,000$ ( $\$ 500,000$ for a married couple) on the sale of a home. ${ }^{50}$ Because the median price of a home in the United States today is about $\$ 200,000,{ }^{51}$ for the overwhelming majority of taxpayers, the exemption is effectively unlimited. But not for the richest. The cap balances tax policy favoring homeownership with appropriate concern for the fisc and for progressive taxation when the sale of a home results in very significant gain.

${ }^{49}$ See Lei, supra note 1.

${ }^{50}$ I.R.C. $\S 121(\mathrm{~b})(1)-(2)$.

${ }^{51}$ Emmie Martin, The Median Home Price in the U.S. is \$200,000-Here's What that Will Get You Across the Country, CNBC (June 29, 2017, 8:00 PM), https://www.cnbc.com/2017/06/29/what-themedian-home-price-of-200000-will-get-you-across-the-us.html.

Pitt Tax Review | ISSN 1932-1821 (print) 1932-1996 (online) DOI 10.5195/taxreview.2019.95 | http://taxreview.law.pitt.edu 


\section{4 | Pittsburgh Tax Review | Vol. 162019}

A similar approach can and should be taken to $\S 1041$. Whether the cap is set at $\$ 250,000$ or $\$ 500,000$, nothing would change for nearly all divorcing couples. But for the rare few whose divorce settlements include highly appreciated assets - the Thomas and Alice Davises of the world, and their counterparts in community property states as well-capital gains tax (typically at a maximum rate of twenty percent ${ }^{52}$ ) appropriately is due on transfer. For the sake of the Treasury, which is to say, for all our sakes, the very richest divorcing couples should recognize some gain even on ownership changes incident to divorce. Davis, whatever its shortcomings, got that right.

52 Topic 409: Capital Gains and Losses, InTERnAL REvenue SERV., https://www.irs.gov/ taxtopics/tc409 (last updated Mar. 29, 2019).

Pitt Tax Review | ISSN 1932-1821 (print) 1932-1996 (online) DOI 10.5195/taxreview.2019.95 | http://taxreview.law.pitt.edu 